\title{
A study of the relationship between substance abuse and cognitive functions in Ecuadorian subjects
}

\author{
Badanie zależności między nadużywaniem substancji psychoaktywnych \\ a funkcjami poznawczymi w populacji Ekwadoru
}

\begin{abstract}
Jose Luis Vilchez $z^{1,2}$
${ }^{1}$ Department for Management of Science and Technology Development, Ton Duc Thang University, Ho Chi Minh City, Vietnam 2Faculty of Applied Sciences, Ton Duc Thang University, Ho Chi Minh City, Vietnam
\end{abstract}

Neuropsychiatria i Neuropsychologia 2017; 12, 3: 87-94

\author{
Address for correspondence: \\ Ton Duc Thang University \\ Nguyen Huu Street 19 \\ Tan Phong Ward, District 7 \\ Ho Chi Minh City, Vietnam \\ e-mail: vilchez.tornero@tdt.edu.vn
}

\begin{abstract}
Aim of the study: The lack of studies on the cognitive consequences of psychotropic substance abuse makes it necessary to perform an in-depth analysis of its importance. Drug-rehabilitation centres in the Republic of Ecuador do not usually take into account neurocognitive stimulation within the treatments they offer. The aim of the present study is to test the effect of drug abuse in three different cognitive processes (learning, memory, and cognitive flexibility).

Material and methods: To this aim, a version of the Wisconsin test was computerised to evaluate reaction times in diagnosed/consumer and undiagnosed/non-consumer populations.

Results: The results show that diagnosed/consumer population has significantly greater reaction times in the matching tasks than the undiagnosed/non-consumer population; showing more important cognitive deficits in the cognitive areas of learning, memory and cognitive flexibility. On the other hand, there is a positive and significant correlation between time of consumption and the level of cognitive deficit. However, undiagnosed/ non-consumer population significantly commit less number of mistakes in those tasks.

Conclusions: It is recommended that drug-rehabilitation centres include cognitive rehabilitation in their intervention programming.
\end{abstract}

Key words: substance abuse, neuropsychology, cognitive impairment, learning, memory, cognitive flexibility.

\section{Introduction}

The World Health Organisation states that recreational drugs are the major cause of modification of the physical and chemical structures in the Central Nervous System (CNS). In this sense, the consumption of these substances alters both consciousness (Pérez 2000) and behaviour (Cáceres, Salazar, Varela, and Tovar 2006). The most relevant neurotransmitters and neuromodulators of the CNS, on which recreational drugs act directly, are (Méndez et al. 2010): (a) nicotine, on nicotinic acetylcholine receptors; (b) alcohol, on g-aminobutyric acid (GABA) and glutamate N-methyl-D-aspartate (NMDA) receptors; (c) marijuana, on cannabinoid receptors1 (CB1R); (d) morphine and heroin, on endorphins (EDFs); and (e) amphetamines, methylphenidate and cocaine, on the active dopamine transporter (TAD).

In the Republic of Ecuador, addictions to psychotropic substances are among the most relevant public health problems. The National Institute of Statistics and Censuses ([INEC], 2013) of the Republic of Ecuador estimates that there are 912,576 pathological consumers of alcohol. The National Council for the Control of Narcotic and Psychotropic Substances ([CONSEP], 2012) places marijuana and cocaine as the most commonly used illicit drugs. In this sense, the city of Cuenca (where this research takes place) accurately highlights the cities with the highest consumption of marijuana and cocaine in Ecuador. Similarly, CONSEP estimates that $17.17 \%$ of mental and behavioural disorders are caused by alcohol abuse in the Republic 
and that all consumers of illicit drugs are at risk of the development of pathologies. These estimations are not supported by scientific evidence. One of the justifications for this work is the precise quantification of cognitive deficits that the consumption of substances of abuse provokes.

In healthy subjects and in those who have suffered some type of brain damage, the high-level cognitive functions mainly reside on the cerebral cortex (Portellano 2005). In this sense, cognition denotes the ability of acquiring, storing, retrieving, and using the knowledge (Rivas 2008). The cognitive functions are the ones that better enable subjects to adapt to the constant changes of the environment (Castillo, Gómez, and Ostrosky 2009). The causes of cognitive impairment are, among others, cerebrovascular diseases, brain tumours, infections affecting nervous tissue, or psychiatric diseases that produce brain alterations (Junqué and Barroso 2009). Substance use and abuse precisely highlight the para-normative ways of altering neuronal functioning, altering the "functional systems" (in terms of Luria 1973) and, therefore, the cognitive functions linked to them.

One of the most sensitive functions affected by the use and abuse of substances is learning, defined as the process of relatively permanent change in behaviour from the experience. In this sense, the acquisition and modification of knowledge, strategies, skills, beliefs, and attitudes are implicit in the definition (Schunk 1991). Substance abuse has been associated with an increase in the slowness in carrying out this cognitive process, correlating the level of deficit with the severity of the addiction (Ruíz Sánchez de León et al. 2009).

On the other hand, memory impairment is based in an incapacity of the CNS for encoding, storing, organising, or retrieving information (Carrillo-Mora 2010); especially highlighted in the consumption of marijuana (García Fernández, García Rodríguez, and Secades Villa 2011). Likewise, compulsive alcohol consumption has also been related to memory deficit as well as to alterations in executive functions such as planning, self-regulation, impulse control, and decision making (Bausela Herreras 2008).

The so-called executive functions are the most complex functions performed by human beings. These functions are supported by the interaction of nuclei located in the prefrontal cortex, and they allow humans to behave in an independent and profitable way. In general terms, the functions carried out by the prefrontal cortex facilitate the adaptation of the human being to new situations; by modulating more basic and automatic cognitive abilities. In this sense, cognitive flexibility is the ability to change criteria in monitoring strategies for performing tasks.

Executive functions are precisely reported as the most sensitive functions to neuropsychological damage produced by recreational drugs (Madoz-Gordoide and Ochoa-Mangado 2012). Changes in the environment require the ability to inhibit the automatic responses and the performance of strategies. Cognitive flexibility involves the generation and selection of new strategies, among multiple options, to develop a task. The excessive fixation in a criterion, a hypothesis, or a strategy of action has a detrimental effect on problem solving.

The present study focuses on assessing the relationship between substance abuse and the impairment of basic cognitive functions (such as learning and learning consolidation [memory]) and high-level cognitive functions (cognitive flexibility). The main hypothesis is that people who pathologically consume or have consumed will show greater cognitive deficits in the mentioned cognitive areas. The secondary hypothesis is that the longer the drug consumption, the greater the level of cognitive impairment, in line with previous literature (e.g. Ruiz Sánchez de León et al. 2009).

The original contribution of the current research is the use of continuous quantitative variables with measurement units (milliseconds). In this sense, the literature reviewed mainly uses questionnaires to measure cognitive deficits (e.g. Abendaño Zuñiga 2012; Castillo-Parra, Gómez-Perez, and Ostrosky-Solís 2009; Coullaut-Valera, Arbaiza-Díaz del Río, Arrué-Ruiloba, Coullaut-Valera, and Bajo-Breton 2011; Félix 2007; García-Fernández, García-Rodríguez, Secades-Villa, Álvarez Carriles, and Sánchez Hervás 2008; Iraurgi Castillo 2009; Madoz-Gúrpide and Ochoa-Mangado 2012; Méndez Díaz et al. 2010; Rivas Navarro 2008; Rojo-Mota, Pedrero-Pérez, Ruiz Sánchez de León, Llanero-Luque, and Puerta-García 2013; Ruiz Sánchez de León et al. 2009; Torres de Galvis, Posada Villa, Barreño Silva, and Berbesí Fernández 2010). This study is the first, to the best of my knowledge, that probes the three cognitive areas of attention, memory, and cognitive flexibility at the same time in this quantitative manner, thus being able to quantify the differences and the level of impairment between them. 


\section{Material and methods}

\section{Participants}

A total of 151 participants, 33.1\% women $(n=50)$ and $66.9 \%$ men $(n=101)$, took part in this study. Participants' ages ranged from 18 to 63 years $\left(M_{\text {age }}=30.32\right.$ years, $S D_{\text {age }}=12.1$ years). In order to select diagnosed/consumer participants, incidental non-probabilistic sampling was used (Cohen and Manion 1990). On the other hand, to select the population of undiagnosed/non-consumer participants, an accidental non-probabilistic sampling was used. The group of undiagnosed/non-consumer $(n=87$, $57.6 \% ; M_{\text {age }}=29.38$ years, $\left.S D_{\text {age }}=12.21\right)$ participants had not ever received treatment, nor were they diagnosed at any time with recreational drug abuse (International Statistical Classification of Diseases and Related Health Problems [ICD-10]; WHO 1992).

The Diagnosed/consumer group ( $n=64$, $42.4 \%, M_{\text {age }}=31.59$ years, $\left.S D_{\text {age }}=11.94\right)$ had been diagnosed with substance abuse by a rehabilitation centre. Participants were recruited at two centres located in the city of Cuenca, Ecuador. All participants met the diagnostic criteria (WHO 1992) of presenting, at least 12 months prior to the diagnosis, due to physiological, behavioural, and cognitive manifestations of consumption of at least one drug. Participants had a minimal period of consumption of one year.

\section{Methods}

A task was designed to evaluate cognitive functions, based on Wisconsin test cards (Heaton 1981). OpenSesame software (Mathôt, Schreij, and Theeuwes 2012) was used to present stimuli and record participants' responses on an HP Intel ${ }^{\circledR}$ Core $^{\mathrm{TM}} 2 \mathrm{~T} 5500$ (1.66Ghz@1.66GHz, 0.99 RAM GB and Mobile Intel ${ }^{\circledR} 945$ Express Chipset Family screen adapter) computer.

The task presented visual stimuli (cards, see Fig. 1) with different elements. At the top of the image appeared four cards with different shapes (i.e. circles, crosses, stars, or squares), with different colours (blue, green, yellow, or red) and different numbers of elements (one, two, three, or four). At the bottom, a card-criterion appeared. This fifth card had to be paired with only one of the other four cards, according to the different criteria along the experimental blocks: (a) training block; (b) consolidation block; and (c) contrast block. Reaction Times (RTs) in matching the cards

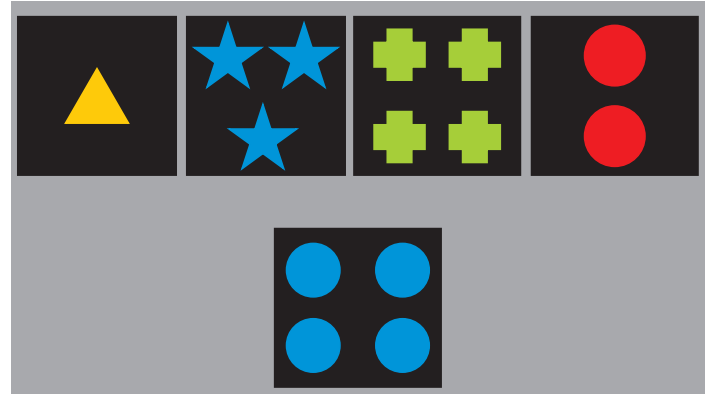

Based in the Wisconsin test (Félix 2007)

Fig. 1. Example of images with cards used in the task

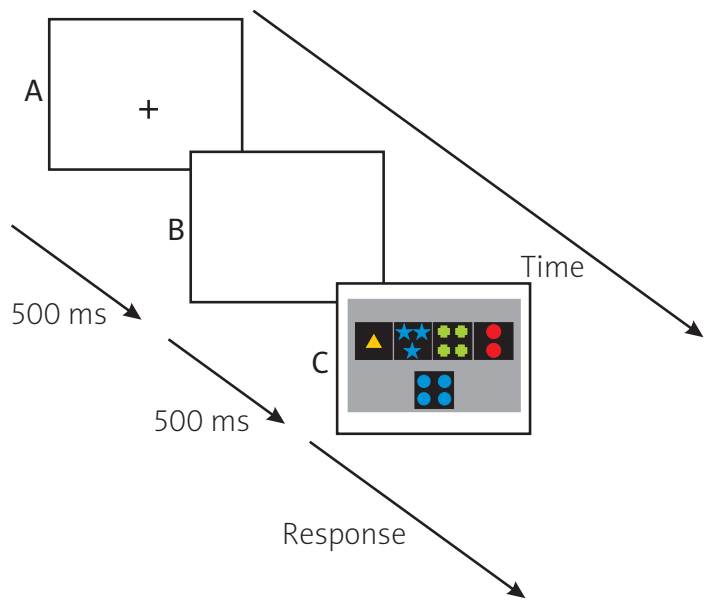

Sequence: (A) fixation point; (B) blank image; (C) images of cards

Fig. 2. Schemata of the task sequence

using different criteria (e.g. matching colours or matching shapes) were recorded.

The experimental task sequence was the presentation of: (a) a fixation point in the centre of the image; (b) a blank image for $500 \mathrm{~ms}$; and (c) an image with the four top cards and the card-criterion (see Fig. 2). Different matching criteria were used in each block.

The first block (training block; learning function) consisted of five trials (see Fig. 3) randomly presented. Participants were instructed to follow a matching-criterion of colour. This block was the only one in which participants were given feedback on their execution, and only for incorrect responses. In the second block (consolidation block; consolidation of learning or memory function, see Fig. 3), a matching-criterion of form was used. This block consisted of 20 randomly presented trials without feedback. Finally, the last contrast block (cognitive flexibility, see Fig. 3) used a matching-criterion of number of elements on the cards. This last block consisted of a single trial also without feedback. 


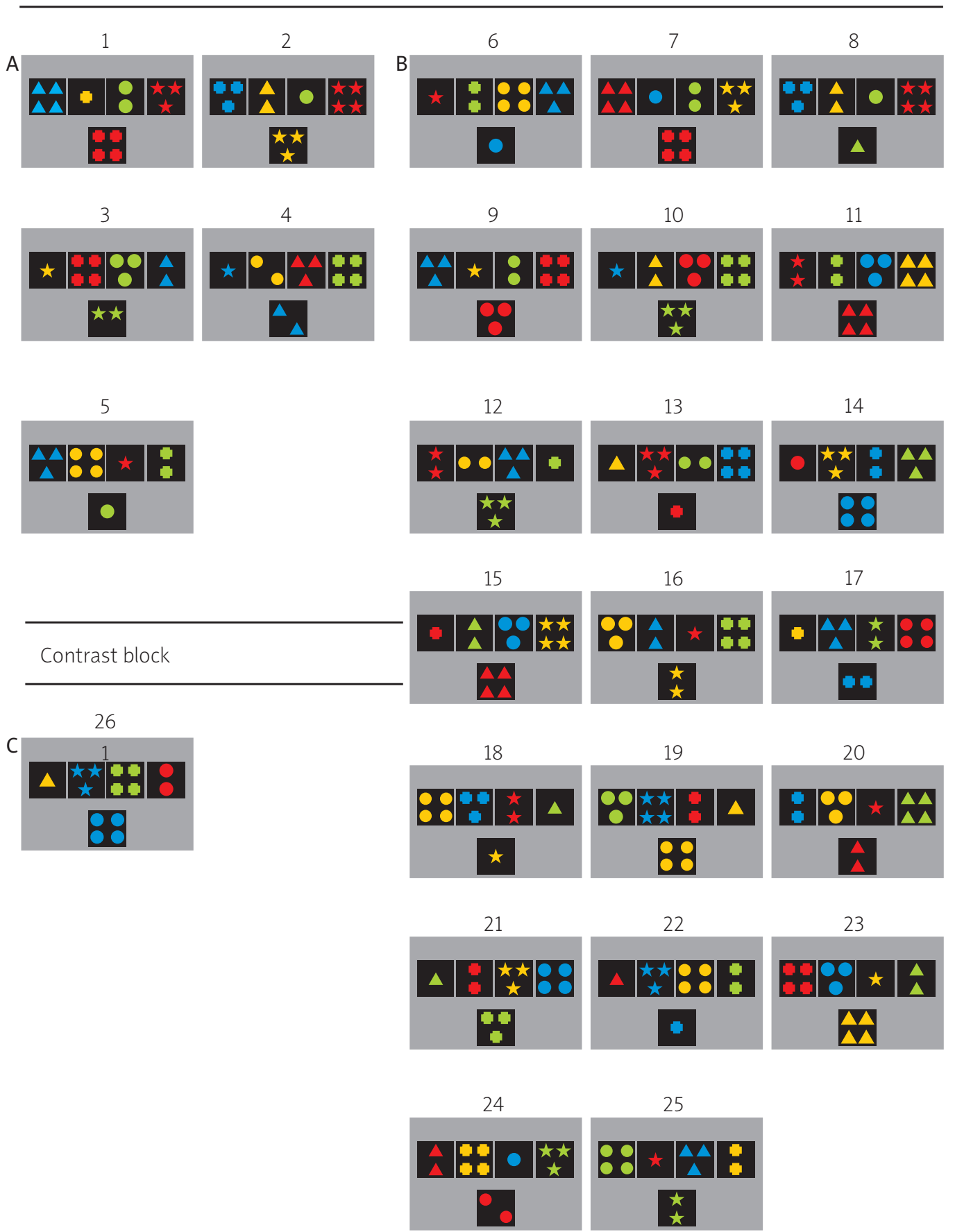

Fig. 3. Experimental images for blocks: (A) training block; (B) consolidation block; and (C) contrast block

\section{Procedure}

All participants fulfilled an informed consent form prior to their participation, with no reward received. Once the time of consumption of any drug was registered, the experimental task was presented on the computer screen. The diagnosed/consumer group was evaluated in the offices of the rehabilitation centres and the undiagnosed/non-consumer group was evaluated in the laboratory.

\section{Experimental design}

Quasi-experimental design. RTs for each of the designed blocks (training block, consolidation block, and contrast block, see Fig. 3; dependent variable [VD]) were compared for diagnosed/consumer and undiagnosed/non-consumer participants (independent variable [VI] of selection).

Correlation between Consumption Time and Reaction Time. The consumption time (CT) 
was measured by the months of consumption (predictive variable [PV]). The RT was sum of all RTs from all experimental blocks (criterion variable $[\mathrm{CV}]$ ).

Correlation between consumption and number of errors. On the one hand, the ICD-10 diagnosis divided participants into diagnosed/consumer and undiagnosed/non-consumer groups (consumption). On the other hand, the number of errors (NE) committed by participants was counted for the training block (learning), consolidation block (memory), and contrast block (cognitive flexibility) to analyse the significant correlation between these two nominal variables.

\section{Data analysis}

The statistical assumptions were tested with: (a) the Kolmogorov-Smirnov test for the goodness of fit to a normal distribution; and (b) the $F$ of Levene for determining the homogeneity of the variances of the two distributions of data for both quasi-experimental and correlational CT-RT designs.

Having verified the statistical assumptions, in the case of the quasi-experimental comparison, a $t$ Student test was used to compare RTs between both groups (diagnosed/consumer and undiagnosed/non-consumer groups), determining the size of the effect with a Cohen's $d$. On the other hand, the correlation between CT and RT was tested with Spearman's rho because the variances of both groups in this variable were non-homogeneous.

The contingency table of the crossing between the consumption (diagnosed/consumer and undiagnosed/non-consumer) and NE variables was analysed using the Chi-square test in the case of an expected frequency greater than five in all cells (otherwise Fisher's exact statistics was used). In both cases, the size of the effect was estimated by Cramer's $V$.

\section{Results}

\section{Quasi-experimental analysis}

The distribution of RTs in the training block followed a normal distribution, $Z(151)=2.51$, $p<.001$. The variances of the distributions of both groups were homogeneous, $F(149)=$ $2.96, p>.250$. There were significant differences in the RTs in the training block between the diagnosed/consumer and undiagnosed/ non-consumer groups, $t(149)=2.33, p<.022$, $d=.38$, small size effect (Cohen 1969; Lipsey 1990). Regarding the direction of the effect,
RTs in the training block for the undiagnosed/ non-consumer group were significantly lower $(M=4,855.82 \mathrm{~ms}, S D=3,722.65)$ than for the diagnosed/consumer group $(M=6,466.79 \mathrm{~ms}$, $S D=4,760.65$, see Fig. 4). The results show that the diagnosed/consumer group members had learning problems.

The distribution of RTs in the consolidation block also followed a normal distribution, $Z(151)$ $=2.23, p<.001$. The variances of both distributions were homogeneous, $F(149)=1.52$, $p=.219$. There were significant differences in the RTs in the consolidation block between the two groups, $t(149)=2.57, p<.011, d=.42$, small size effect (Cohen 1969; Lipsey 1990). Regarding the direction of the effect, the RTs in the consolidation block for the undiagnosed/ non-consumer group were significantly lower $(M=3413.92 \mathrm{~ms}, S D=2,152.87)$ than in the diagnosed/consumer group $(M=4385.86 \mathrm{~ms}, S D$ $=2487.79$, see Fig. 5). These results show that the diagnosed/consumer group members had greater problems of consolidation of learning (memory).

The distribution of RTs in the contrast block followed a normal distribution as well, $Z(151)$ $=2.27, p<.001$. The variances of both dis-

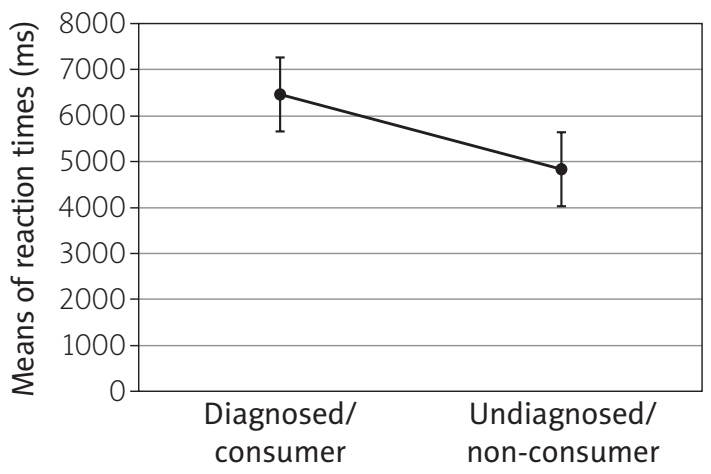

Fig. 4. Means of reaction times in the training block for diagnosed/consumer and undiagnosed/non-consumer groups

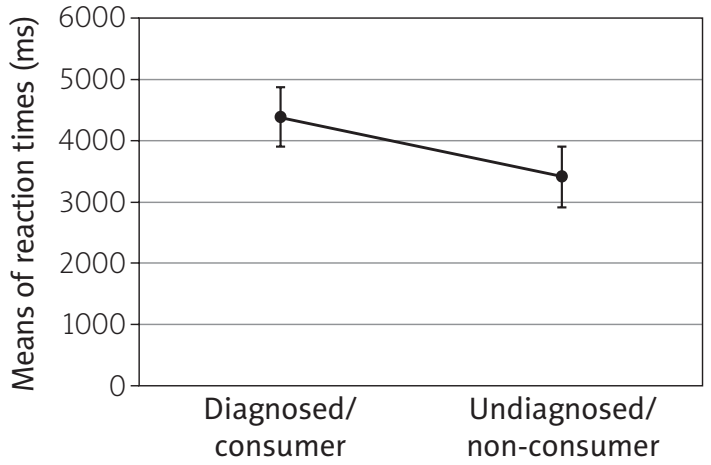

Fig. 5. Means of reaction times in the consolidation block for diagnosed/consumer and undiagnosed/non-consumer groups 


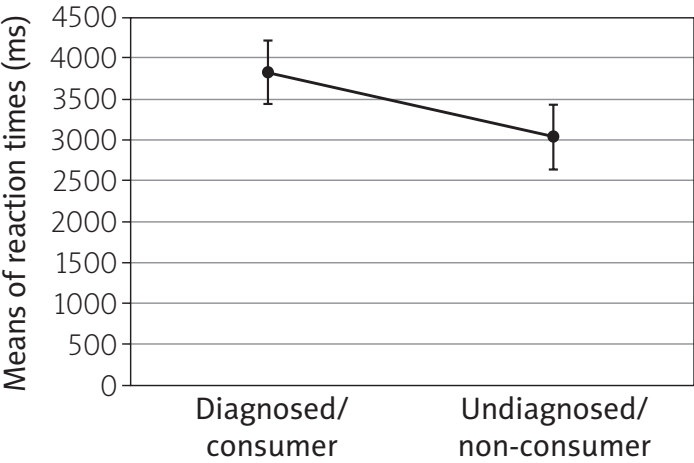

Fig. 6. Means of reaction times in the training block for dia gnosed/consumer and undiagnosed/non-consumer groups

tributions were homogeneous, $F(149)=1.16$, $p>.250$. Significant differences were found between both groups, $t(149)=2.61, p<.011$, $d=.84$; large size effect (Cohen 1969; Lipsey 1990), the largest taking into account all blocks of analysis. Regarding the direction of effect, $\mathrm{RT}$ in the undiagnosed/non-consumer group were significantly lower $(M=3041.23 \mathrm{~ms}$, $S D=1783.71)$ than in the diagnosed/consumer group $(M=3824 \mathrm{~ms}, S D=1872.65$, see Fig. 6). These results show that diagnosed/consumer group had less cognitive flexibility than the undiagnosed/non-consumer group.

The distribution of participants' age followed a normal distribution, $Z(151)=2.34, p<.001$, and the variances of both groups were homogeneous, $F(149)=0.03, p>.250$. There were no significant differences between the average age of the diagnosed/consumer and undiagnosed $/$ non-consumer groups, $t(149)=1.11$, $p>.250$. These results confirm that the groups were equivalent in age.

\section{Correlation between consumption time and reaction time}

Both CT, $Z(151)=2.70, p<.001$, and the total RT, $Z(151)=2.15, p<.001$, followed a normal distribution. The variances of both distributions are non-homogeneous, $F(300)$ $=125.04, p<.001$. There was a significant, weak, positive correlation (Hernández Sampieri, Fernández Collado, and Pilar Babtista, 2007) between both variables, $r_{s}(151)=.187, p<.022$.

\section{Correlation between consumption and number of errors}

A contingency table was created for the training block between the type of population (consumption) and the NE. The diagnosed/ consumer population made significantly fewer errors $(3.44 \%$, see Table 1$)$ than the undiagnosed/non-consumer population $(8.51 \%)$, $X^{2}(755)=7.95, p<.005, V=.103$; small size effect (Lipsey 1990).

Similarly, the diagnosed/consumer population made significantly fewer errors $(3.98 \%$, see Table 1) than the undiagnosed/non-consumer population $(11.21 \%), X^{2}(3020)=51.42$, $p<.001, V=.130$, for the consolidation block; small size effect (Lipsey 1990).

Finally, there were no significant differences between the diagnosed/consumer population (4.69\%, see Table 1) and the undiagnosed/

Table 1. Total correct answers and errors in the different experimental block for Diagnosed/consumer and Undiagnosed/ Non-consumer populations

\begin{tabular}{l} 
Response \\
\cline { 2 - 3 }
\end{tabular}


non-consumer population $(6.9 \%), F(151)=.321$, $p=.250, V=.046$, for the contrast block.

\section{Conclusions}

The present study evaluates the cognitive impairment both in basic cognitive processing such as the learning capacity and consolidation of this learning (memory), and in executive functions such as the cognitive flexibility in the change of criteria. The results show the direct relationship between the multi-consumption of psychotropic substances and the cognitive impairment. The reference group comprised participants who had never consumed or those whose consumption was not diagnosed as substance abuse (WHO 1992).

Learning, learning consolidation, and cognitive flexibility required significantly more time for diagnosed participants than for the non-consumers or the undiagnosed participants. The ability to learn a new task (training block), consolidation of that learning (consolidation block), and the cognitive flexibility of being able to re-learn a new way to perform the task with another criterion (contrast block) are significantly decreased in the diagnosed subjects. The differences in cognitive flexibility are the ones that have a large effect size, in contrast to learning and the consolidation of that learning. Therefore, it can be affirmed that the executive functions are the ones that deteriorated more along with consumption (Madoz-Gordoide and Ochoa-Mangado 2012). The present study tests these cognitive functions along with learning and consolidation of those learning abilities. However, the age variable did not show significant differences between the both groups, which invalidates the strange variable of age as a possible explanation for these differences. Therefore, these results cannot be attributed to the age variable because both groups are equivalent from the beginning.

Likewise, there is a significant correlation between the CT of any substance and the total $\mathrm{RT}$ in the task accomplishment (including the RTs of all experimental blocks). Regardless of the type of substance, there is a weak, significant, and positive relationship; the longer the consumption time, the greater the cognitive impairment in general terms (taking into account the total execution). In other words, subjects who had consumed for a longer time took longer to perform the tasks (independently of a specific cognitive area).
Surprisingly, the results reveal that the diagnosed participants performed tasks with a significantly lower proportion of errors than undiagnosed individuals as consumers or simply non-consumers. The diagnosed participants showed a more conservative criterion in the learning and the consolidation of that learning due to their condition of intern in rehabilitation centres. Participants in this situation might have been under pressure to make "no mistake" and to follow guidelines (typical of the period of rehabilitation).

In conclusion, the results show the influence of the consumption of psychotropic substances on cognitive functions (learning, consolidation of learning, and cognitive flexibility) in a more quantitative way than in previous studies (e.g. Abendaño Zuñiga 2012; Madoz-Gordoide and Ochoa-Mangado 2012; Serrani 2009).

These findings support the recommendation to rehabilitation centres to work with cognitive stimulation within the rehabilitation process, since the capacity of these cognitive functions help patients to adapt themselves to the environment (Valle Arias, Barca Lozano, González Cabanach, and Núñez Pérez 1999). These cognitive functions constitute important areas of daily life, contribute to their quality of life and are not present in drug rehabilitation programs (according to the centres consulted). Learning and consolidating a new way of living, and being flexible in the means of changing life, determine the success of psychological therapy in this type of circumstances.

\section{References}

1. Abendaño Zuñiga CM. Deterioro de las funciones cognitivas y su relación con el trastorno de dependencia a sustancias psicotrópicas, en los internos de los centros terapéuticos "salvando al adicto" y "camino hacia la libertad" de la ciudad de Loja [Impairment of cognitive functions and their relationship with psychotropic substance dependence disorder, in the inmates of the therapeutic centers "saving the addict" and "the path to freedom" in the City of Loja] (Gade thesis). Universidad Nacional de Loja, Loja, Ecuador. Available at: https://goo.gl/uFFJhq.

2. Bausela Herreras E. Neuropsicología y adicciones. Revista Chilena de Neuropsicología 2012; 3: 1-3. Available at: https://goo.gl/AhJsio.

3. Carrillo-Mora P. Sistemas de memoria: Reseña histórica, clasificación y conceptos actuales. Primera parte: Historia, taxonomía de la memoria, sistemas de memoria de largo plazo: la memoria semántica [Memory systems: historical background, classification, and current concepts. Part one: History, taxonomy of memory, long-term memory systems: Semantic memory]. Salud Mental 2010; 33: 85-93. Available at: https://goo.gl/IXKISP.

4. Castillo-Parra G, Gómez-Perez E, Ostrosky-Solís F. Relación entre las funciones cognitivas y el nivel de desar- 
rollo académico de los niños [Relationship between cognitive functions and the level of academic development of children]. Revista Neuropsicología, Neuropsiquiatría y Neurociencias 2009; 9: 41-54. Available at: https://goo. gl/ZJ2M4V.

5. Cohen J. Statistical Power Analysis for the Behaviora Sciences. Laurence Erlbaum, New Jersey 1969. Available at: https://goo.gl/VpTMOC.

6. Cáceres D, Salazar I, Varela M, Tovar J. Consumo de drogas en jóvenes universitarios y su relación de riesgo y protección con los factores psicosociales [Drug use in University students and their risk and protection rela tionship with psychosocial factors]. Revista Universitas Psychologica 2006; 5: 521-534. Available at: https://goo. gl/ppPcul.

7. Coullaut-Valera R, Arbaiza-Díaz del Río I, de Arrué-Ruiloba $R$, et al. Deterioro cognitivo asociado al consumo de diferentes sustancias psicoactivas [Cognitive impairment associated with the consumption of different psychoactive substances]. Actas Españolas de Psiquiatría 2011; 39: 168-173. Available at: https://goo.gl/KtqjeM.

8. Félix VM. Funciones ejecutivas: Estimación de la flexibi lidad cognitiva en población normal y un grupo psicopatológico [Executive functions: Estimating cognitive flexibility in a control and a psychopathological group] 2007. Available at: https://goo.gl/h8VmFe.

9. García Fernández G, García Rodríguez O, Secades Villa R. Neuropsicología y adicción a drogas [Neuropsychology and drug addiction]. Papeles del Psicólogo 2011; 32: 159165. Available at: https://goo.gl/A5MOVl.

10. García Fernández G, García-Rodríguez O, Secades-Villa $\mathrm{R}$, et al. Rendimiento neuropsicológico de pacientes en tratamiento por adicción a la cocaína [Neuropsychological performance of patients under treatment for cocaine addiction]. Salud y drogas 2008; 8: 11-27. Available at: https://goo.gl/qIA1HZ.

11. Hernández Sampieri S, Fernández Collado C, Pilar Babtista L. Metodología de la Investigación [Research methodology] (4 ${ }^{\text {th }}$ ed.). McGraw-Hill Interamericana, México 2007.

12. Instituto Nacional de Censos y Estadísticas del Ecuador. Encuesta Nacional de Ingresos y Gastos de los hogares urbanos y rurales 2011-2012 [National Revenue and Expenditure of urban and rural households 2011-2012]. Available at: https://goo.gl/5M2Lto.

13. Iraurgi Castillo I. Evaluación de resultados clínicos (II): Las medidas de la significación clínica o los tamaños del efecto [Evaluation of clinical outcomes (II): Measures of Clinical significance or effect sizes]. Norte de Salud Mental 2009; 8: 94-110. Available at: https://goo.gl/iCit6q.

14. Junqué C, Barroso J. Envejecimiento, demencias y otros procesos degenerativos [Aging, dementias and other processes degenerative]. In C. Junqué and $M$. de los $A$. Jurado (eds.), Manual de Neuropsicología [Manual of Neuropsychology] (pp. 229-230). Editorial Sintesis S.A., Madrid 2009. Available at: https://goo.gl/h9zfrN.

15. Madoz-Gúrpide A, Ochoa-Mangado E. Alteraciones de funciones cognitivas y ejecutivas en pacientes dependientes de cocaína: Estudio de casos y controles [Alterations of cognitive and executive functions in cocaine dependent patients: Case-control study]. Revista de Neurología 2012; 54: 199-208. Available at: https://goo.gl/uwnXxB.

16. Mathôt S, Schreij D, Theeuwes J. OpenSesame: An open-source, graphical experiment builder for the social sciences. Behavior Research Methods 2012; 44: 314-324. doi: 10.3758/s13428-011-0168-7.

17. Méndez Díaz M, Ruiz Contreras AE, Prieto Gómez B, et al. El cerebro y las drogas: Sus mecanismos neurobio- lógicos [The brain and drugs: Their neurobiological me chanisms]. Salud mental 2010; 33: 451-456. Available at: https://goo.gl/AzBxGX.

18. Lipsey MW. Design Sensitivity: Statistical Power for Experimental Research. Sage, London 1990.

19. Luria AR. The working brain: An introduction to Neuropsychology. Basic Books, New York 1973.

20. Observatorio Nacional de Drogas. Boletín Informativo Observando [Observing Newsletter]. CONSEP, Quito 2012. Available at: https://goo.gl/BzIZU9.

21. Organización Mundial de la Salud. Neurociencia del consumo y dependencia de sustancias psicoactivas [Neuroscience of consumption and dependence onpsychoactive substances]. OPS, Washington 2005. Available at: https://goo.gl/sql7aO.

22. Organización Mundial de la Salud. Trastornos Mentales y del Comportamiento [Mental and Behavioral Disorders]. Meditor, Madrid 1992.

23. Portellano JA. Introducción a la Neuropsicología [Introduction to Neuropsychology]. McGraw-Hill, Madrid 2005

24. Rivas Navarro M. Procesos cognitivos y aprendizaje significativo [Cognitive processes and meaningful learning] BOCM, Madrid 2008. Available at: https://goo.gl/OLGvBr.

25. Rojo-Mota G, Pedrero-Pérez EJ, Ruiz-Sánchez de León JM, et al. Cribado neurocognitivo en adictos a sustancias: La evaluación cognitiva de Montreal [Neurocognitive screening in Addicts: The cognitive evaluation of Montreal]. Revista de Neurología 2013; 56: 129-136. Available at: https://goo.gl/RTVoqS

26. Ruiz Sánchez de León JM, Pedrero-Pérez E, Llanero Lluque $M$, et al. Perfil neuropsicológico en la adicción a la cocaina: Consideraciones sobre el ambiente social próximo de los adictos y el valor predictivo del estado cognitivo en el éxito terapéutico [Neuropsychological profile in cocaine addiction: Considerations about the social environment close to addicts and the predictive value of $\mathrm{Co}$ gnitive status in therapeutic success]. Revista Adicciones 2009; 21: 119-132. Available at: https://goo.gl/bJl4dU.

27. Serrani D. Evaluación neuropsicológica de drogodependientes duales a alcohol y cocaína en periodo avanzado de abstinencia [Neuropsychological evaluation of dual drug addicts to alcohol and cocaine in an advanced period of abstinence]. Revista Neuropsicología, Neuropsiquiatría y Neurociencias 2009; 9: 93-113. Available at: https://goo.gl/PezRfg.

28. Torres de Galvis Y, Posada Villa J, Barreño Silva J, Berbesí Fernández DY. Trastornos por abuso y dependencia de sustancias en población colombiana: Su prevalencia y comorbilidad con otros trastornos mentales seleccionados [Substance abuse and dependence disorders in Colombian population: Their prevalence and comorbidity with other selected mental disorders]. Revista Colombiana de Psiquiatría 2010; 39: 14-35. Available at: https:// goo.gl/1da5lR.

29. Valle Arias A, Barca Lozano A, González Cabanach R, Núñez Pérez JC. Las estrategias de aprendizaje: Revisión teórica y conceptual [Learning strategies: Theoretical and conceptual review]. Revista Latinoamericana de Psicología 1999; 31: 425-461. Available at: https://goo.gl/3BsOgz. 